\title{
The Feasibility of the Mise en Place Restaurant Video Tutorial as a Learning Medium
}

\author{
Rina Febriana Hendrawan ${ }^{1, *}$ Yeni Yulianti ${ }^{2,}$ Lita Rosita $^{2}$ \\ ${ }^{1}$ Technology and Vocational Education, Universitas Negeri Jakarta, Indonesia \\ ${ }^{2}$ Faculty of Engineering, Universitas Negeri Jakarta, Indonesia \\ ${ }^{*}$ Corresponding author. Email: rinafebriana@unj.ac.id
}

\begin{abstract}
Learning media is a teaching aid used to convey information or messages. It can stimulate students' willingness to create the teaching and learning process. One type of learning media used is video learning. This study aims to determine the Restaurant Mise en Place video tutorial instructional media's feasibility level and investigate student responses regarding the Restaurant Mise en Place video tutorial instructional media. This study uses the Research and Development method with the analysis, design, develop, implement, and evaluate (ADDIE) development model. In the feasibility test, the percentage obtained was $84 \%$ (good), the results obtained in the small group test were $91 \%$ (very good), and the field tests produced a percentage of $93 \%$ (very good). The student responses made a percentage of $94 \%$ (very strong), which means that the learning media is well qualified and suitable for use as a learning media in the field administration course.
\end{abstract}

Keywords: Learning Media, Restaurant Mise en Place Material, Video Tutorial

\section{INTRODUCTION}

At the beginning of 2020, the world experienced a major disaster. The spread of Coronavirus, that is commonly known as COVID-19, is rapidly attacking the whole world. The pandemic affected an estimated 1.7 billion students. During the pandemic, there is a change in assessment and learning, and this process is carried out remotely by involving all elements simultaneously. The components involved are students, teachers, and parents [1]. Online learning has occurred almost all over the world due to the impact of the COVID-19 pandemic [2]. The effects of the pandemic have also led to a complete migration of all elements of education, from hands-on learning in the classroom to distance education [3].

With the issuance of Circular Number 4 of 2020 regarding the Covid-19 pandemic, all educational institutions carry out distance learning. Relevant tools have been needed in distance learning, especially for practicum courses [4]. As a solution in distance learning, the role of information and communication technology (ICT) literacy is vital [5]. Through this research, it is then needed to develop learning media for mise en restaurant video tutorials as a solution in learning.

In this modern era, information and technology affect the dissemination of new information and knowledge quickly and can be accessed by anyone who needs it. According to Lase [6], the Industrial Revolution 4.0 has brought changes in various aspects of human life. One of them is the education system. The technology advancement results have extended its use in education. A set of tools used by educators in communicating with students is called learning media [7]. Learning media is a means of delivering information from the sender to the recipient so that what had offered can be well received. Teachers must make the learning process more creative, communicative, and innovative to learn more optimally both independently. Besides, in class, they must know how they can use communication and information technology to develop various learning media. It is important to develop learning media as an effort to improve students' understanding during the learning process. 


\section{LITERATURE REVIEW}

\subsection{Video Tutorial Restaurant Mise en Place}

In learning, many types of learning media can be used by educators in delivering learning materials, one of which is video tutorial media. Arsyad [8] said that video media is classified as audio-visual media. Wahyuni et al. [9] noted that audio-visual media is an alternative means of technology-based learning that can optimize learning. Ljubojevic et al. [10] said that complementary video content in teaching materials affects motivation and learning efficiency factors. According to Reiss et al. [11], the media can state that video media is well received in education following the case studies presented.

Learning using video tutorial media will make learning more interesting and accessible than audio or visual media. Hananta and Sukardi [12] said that the media in videos would attract the attention of passive students who become active and will not be curious about the process. Devaney [13] wrote about the impact of video tutorials on positive effects on education. Mendoza et al. [14] said that video was very effective for learning.

They developed the video tutorial media based on the characteristics of learning videos. Ahmadi \& Ibda [15] argued that the characteristics of learning videos consisting of clarity of massage, stand-alone, userfriendly, content representation, visualization with media, using high-resolution quality, can be used classically or individualized so that videos can be easy to use both with and without educators. The development of video tutorials applies the stages of analysis, design, develop, implement, and evaluate (ADDIE models). The video had interpreted that the course Restaurant Mise en Place teaches knowledge and skills in the learning process. It had also stated by Cheung [16] that the ADDIE model can be easy to use and can apply to the curriculum that teaches knowledge or skills. In learning media development, this tutorial video uses the ADDIE model. This process is very sequential; every step before the next process had revised according to the ADDIE model chart. The video has done so that there are no mistakes in the process of developing learning media.

Video tutorial learning media is widely known by students, easy to use, and used outside the classroom. Information obtained from 21 students of the Catering study program, as many as $95.2 \%$ of students already know video tutorials as learning media, and $100 \%$ of students stated that video tutorial learning media is easy to use. In addition, as many as $100 \%$ of culinary students stated that the video tutorial learning media was easy to use. In its use, as many as $90.5 \%$ of Culinary students also said the lessons would be easy to understand by using video tutorials. Fauzan and Rahdiyanta [17], in their research, wrote that video media is efficient because it is a .mp4 file and can be used directly with a computer or laptop.

Therefore, video tutorial instructional media development designed to be effective and practical for students is significant. This research aims to determine the feasibility of video tutorial instructional media to help to learn restaurant mise en place in the field administration course.

\subsection{ADDIE Model}

ADDIE is one of the systematic learning design models. Romiszowski (1996), referred to in Tegeh et al. revealed that at the level of learning material design and development, systematic as a procedural aspect of a systematic approach had been manifested in many methodological practices for the design and development of texts, audiovisual materials, and computer-based learning materials [18].

Waneva \& Darmansyah argued that the ADDIE model is often used to describe a systematic approach to instructional development and instructional design is an organized, effective, and efficient process in creating an instructional system to solve learning problems or improve student performance through a series of problem identification, development, evaluation, as well as ADDIE models is a learning model that is general and suitable to be used for developing research that had applied in teaching knowledge and skills [19].

The ADDIE model is programmed with systematic sequences of activities to solve learning problems related to learning resources according to the needs and characteristics of learning. Learning media development with the ADDIE model solves issues in the learning process, especially in the Restaurant Mise en Place material.

\section{METHOD}

Development of video tutorials using the Research and Development method. The model adopted is the ADDIE model. The analysis phase results obtained primary and secondary data to identify student needs. The design stage is the stage of document preparation for production. Document content outlines media content, material descriptions, video scripts, and storyboards. The development stage is an activity in the process of making videos. Validation has been carried out by material experts, media experts, and linguists to get good video results in making videos. The implementation phase is a video application activity that involves students. At this stage, students fill out a questionnaire by marking a checklist $(\sqrt{ })$ in the available column according to their choice. The 
evaluation stage consists of one-on-one assessment, small group evaluation, and extensive group evaluation. At this implementation stage, tests have been carried out to test the products developed and test student responses to the developments that have been developed. To assess the media, use the following formula:

Percentage $=\left(\sum \mathrm{x}\right) / \mathrm{SMI} \times 100 \%$

Information:

$\sum x=$ total score

SMI = Maximum Ideal Score

Table 1. Eligibility percentage scale

\begin{tabular}{l|l|l|}
\hline Achievement Level & Qualification & Information \\
\hline $90 \%-100 \%$ & Very good & Very Feasible, No Need to Revise \\
\hline $75 \%-89 \%$ & Good & Eligible, Revised as Required \\
\hline $65 \%-74 \%$ & Enough & Decent enough, pretty much revised \\
\hline $55 \%-64 \%$ & Less & Not feasible, much revised \\
\hline $0-54 \%$ & Very less & Not feasible, total revision \\
\hline
\end{tabular}

Source: Tegeh, et al. [18]

Table 2. Student response percentage scale

\begin{tabular}{|l|l|}
\hline Achievement Level & Information \\
\hline $0-20 \%$ & Very weak \\
\hline $21-40 \%$ & Weak \\
\hline $41-60 \%$ & Enough \\
\hline $61-80 \%$ & Strong \\
\hline $81-100 \%$ & Very strong \\
\hline
\end{tabular}

To obtain data from student response sheets, the following formula is used:

$$
\text { Interval }=\frac{\text { the score of the statement item }}{\text { highest score statement item }} \times 100 \%
$$

\section{RESULT AND DISCUSSION}

This video tutorial had been tested for students to measure the level of eligibility and determine the students' response to this video tutorial. The following are the results of student trials.

\subsection{One to One Evaluation}

Trial of the revised learning video media through the small group evaluation stage. The result of the calculation, which has been converted to the level of achievement above, shows a percentage value of $84 \%$, which is included in the good qualifications with the appropriate information and revised as necessary. In this procedure, improvements are also made at the suggestion of the validator. Directions based on one-on-
Furthermore, to calculate the percentage of the whole subject, the formula is used:

Percentage $=\mathrm{F}: \mathrm{N}$

Information:

$\mathrm{F}=$ total percentage of subjects

$\mathrm{N}=$ many subjects

In order to provide meaning and decision making, the following provisions are used: 
when watching the learning time tutorial video. The calculation results converted to the level of achievement above show a percentage value of 93\%, which includes excellent qualifications with very decent information and does not need to be revised. To find out the overall student response to the restaurant mise en place video tutorial in this study, it can see in Table 3.

Table 3. Student response results

\begin{tabular}{l|l|l|l|}
\hline No. & Aspects & Indicator & Score \\
\hline 1. & Interest & - Cultivate curiosity & 137 \\
& & - Increase motivation to learn & 138 \\
\hline 2. & Satisfaction & - Retention of material & 143 \\
& & - Give experience & 142 \\
& & - Practical to use & 145 \\
\hline \multicolumn{2}{l|}{ Total Score } & & 705 \\
\hline
\end{tabular}

The assessment results showed that the student's response to the feasibility of the video tutorial got a percentage of $94 \%$, which was in the very feasible category. This assessment shows that students feel interested and satisfied by giving positive feelings to the restaurant mise en place tutorial video. The material expert's estimate got $89 \%$ in the excellent category. The video tutorial is by the learning objectives. The video has based on the theory put forward by Sadiman et al. that learning objectives can provide direction where students are going, how students should get there, and how students know that they have arrived at their destination. The media expert's rating got $86 \%$ in the excellent category. This score means that the media created can help learn to be efficient and effective in its use. This result is also in line with Martiani \& Tetep, 2018 which mention that video tutorial learning media makes learning effective and efficient [21]. The assessment of linguists got $92 \%$ in the outstanding category.

Daryanto in Faryanti et al. argued that messages conveyed through videos are more attention-grabbing [22]. This element of attention is important in the learning process because, with attention, there will be stimulation/motivation to learn. The great attention of students will affect the learning experience. Based on the results of expert validation and student assessment, it is interpreted that the media created already meets the characteristics of learning videos and can increase the motivation and effectiveness of its users. In line with what Riyana refers to from Ahmadi \& Ibda, to produce learning videos that can increase user motivation and effectiveness, the development of learning videos must pay attention to their characteristics [15].

Based on the evaluation test data in the description above, this tutorial video can be used as a learning medium. These results are by the theory of Sadiman et al. [23]. Learning media are everything that media can use to convey messages from sender to receiver to stimulate students' thoughts, feelings, concerns, and interests.

Videos are made in mp4 format and can be used directly with a computer or laptop. Fauzan and Rahdiyanta also wrote that video-based media is very practical because it is an mp4 file and can be used directly with a computer or laptop. In addition, users will package this video with a CD-R that will work with a CD-ROM to make it easier to use in the learning process [17].

\section{CONCLUSION}

The development of the video tutorial media restaurant mise en place using ADDIE development model is considered feasible to use. This study concludes that restaurant the mise en place video tutorial is suitable for learning. In the development of video tutorial media for restaurant mise en place, students' response data had been obtained during the field group evaluation. Student responses showed result of $94 \%$ with solid qualifications. Students' responses on the video tutorials expressed interest and satisfaction in the video tutorial mise en place and showed its worth of learning.

\section{AUTHORS' CONTRIBUTIONS}

The author contributed in increasing the effectiveness of learning by applying video tutorials to the Restaurant Mise en Place material.

\section{ACKNOWLEDGMENTS}

This work was supported by Lembaga Penelitian dan Pengabdian Masyarakat (LPPM), Universitas Negeri Jakarta, under Grant Number: 5/PPI/LPPM/IV/2021, April 26, 2021. 


\section{REFERENCES}

[1] L. Sun, Y. Tang, and W. Zuo, "Coronavirus pushes education online," Nat. Mater., vol. 19, no. 6, 2020, pp. $687 . \quad$ DOI: https://doi.org/10.14421/jpai.2021.181-06

[2] K. Goldschmidt, "The COVID-19 Pandemic: Technology use to Support the Wellbeing of Children," J. Pediatr. Nurs., vol. 53, no. xxxx, 2020, pp. 88-90. DOI: 10.1016/j.pedn.2020.04.013

[3] W. Bao, " COVID -19 and online teaching in higher education: A case study of Peking University ,"Hum. Behav. Emerg. Technol., vol. 2, no. 2,2020, pp. 113-115. DOI: https://doi.org/10.1002/hbe2.191

[4] Minister of Education and Culture Circular Letter No. 4 of 2020 concerning the Implementation of Educational Policies in the Emergency Period for the Spread of Corona Virus Disease (Covid19).Available: https://setkab.go.id/en/educationministry-adjusts-several-policies-amid-covid-19/

[5] Abdul Latip, "The Role of Information and Communication Technology Literacy in Distance Learning During the Covid-19 Pandemic," EduTeach J. Edukasi dan Teknol. Pembelajaran, vol. 1, no. 2, 2020, pp. 108-116. DOI: 10.37859/eduteach.v1i2.1956

[6] D. Lase, "Education and Industrial Revolution 4.0," Handayani J. PGSD FIP Unimed, vol. 10, no. 1,2019 , pp. 48-62. DOI: https://doi.org/10.24114/jh.v10i1.14138

[7] H. Budiman, "The Role of Information and Communication Technology in Education," $J$. Pendidik. Islam, vol. 8, no.1, 2017, pp. 75-83. DOI: https://doi.org/10.24042/atipi.v8i1.2095

[8] A. Arsyad, Learning Media. Jakarta: Rajawali Pers, 2017.

[9] W. Tri, W. Arif, and A. Isa, "The Effectiveness of Using Audiovisual Media on Energy Learning in Living Systems for Middle School Students," Ef. Pengguna. Media Audiov. Pada Pembelajaran Energi Dalam Sist. Kehidup. Pada Siswa SMP. Unnes Sci. Educ. J., vol. 4, no. 3, 2015. pp. 9981004. DOI: $10.15294 /$ usej.v4i3.8848

[10] M. Ljubojevic, V. Vaskovic, S. Stankovic, and J. Vaskovic, "Using supplementary video in multimedia instruction as a teaching tool to increase efficiency of learning and quality of experience," Int. Rev. Res. Open Distance Learn., vol. 15, no. 3, 2014, pp. 275-291. DOI: https://doi.org/10.19173/irrodl.v15i3.1825

[11] N. Reiss, A. K. Bavendiek, G. Diestmann, D. Inkermann, A. Albers, and T. Vietor, "Understanding Design Methods - Using
Explanatory Videos for Knowledge Transfer in Engineering Disciplines," Procedia CIRP, vol. 60, 2017, pp. 518-523. DOI: https://doi.org/10.1016/j.procir.2017.01.033

[12] R. O. Hananta and T. Sukardi, "Development of Video Media Models in Lathe Machining Practice Learning," J. Din. Vokasional Tek. Mesin, vol. 3, no. 2, 2018. pp. 121-129. DOI: $\underline{10.21831 / \text { dinamika.v3i2.21409 }}$

[13] T. a DeVaney, "Impact of video tutorials in an online educational statistics course," J. Online Learn. Teach., vol. 5, no. 4, 2009, pp. 600-608.

[14] G. L. L. Mendoza, L. C. Caranto, and J. J. T. David, "Effectiveness of Video Presentation to Students' Learning," Int. J. Nurs. Sci., vol. 5, no. 2, 2015. pp. 81-86. DOI: doi:10.5923/j.nursing.20150502.07

[15] F. Ahmadi, H. Ibda, School Media Literacy (Theory and Practice). Semarang: CV. Pilar Nusantara, 2018.

[16] L. Cheung, "Using the ADDIE Model of Instructional Design to Teach Chest Radiograph Interpretation" Journal of Biomedical Education, 2016, pp. 1-6. DOI: https://doi.org/10.1155/ 2016/9502572

[17] M. A. Fauzan and D. Rahdiyanta, "Development of Video-Based Learning Media," vol. 2, no.2,2017, pp. 82-88. DOI: 10.21831/dinamika.v2i2.15994

[18] M. Tegeh, N. Jampel, and K. Pudjawan, "Development Research Model". Jogjakarta: yogyakarta: Graha Ilmu, 2014.

[19] A.D. Waneva, Darmansyah, " Development of Audio Visual Media in Learning English Vocabulary for Class VII Junior High School Students ", Journal of Educational Technology, vol. 02, no. 01, 2020, pp.1-6. DOI: https://doi.org/10.24036/inovtech.v2i01.92

[20] A. S. Sadiman, R. Rahardjo, A. Haryono, and Harjito, "Educational Media: Definition, Development, and Utilization". Jakarta: Rajawali Pers, 2014.

[21] D.U. Martiani, Tetep, "The Effectiveness Of Using Video Tutorial To Improving Learning Motivation Of Civid Education", Journal Civics and Social Studies, vol. 2 no, 2019, pp.105-115. DOI: 10.31980/2655-7304.v2i2.515

[22] H. Faryanti, R.G.P Panjaitan, Yokhebed, "Student responses to additive animation films", Journal of Education and Learning Khatulistiwa, vol. 5 no. 3, 2016. Available: https://jurnal.untan.ac.id/ index. php/jpdpb/about 